AJIE - Asian Journal of Innovation and Entrepreneurship

(e-ISSN: 2477- 0574; p-ISSN: 2477-3824)

Vol. 02, No. 02, May 2017

\title{
INCREASING THE WELFARE OF THE CIVIL SOCIETY THROUGH THE RECYCLE OF WASTE CASHEW
}

\author{
Mei Indrawati, Dwi Lesno Panglipursari, Rachmat Hidayat Kurniawan
}

Faculty of Economic and Business, University Wijaya Putra, Surabaya, Indonesia

*Corresponding E-mail : meiindrawati@uwp.ac.id

\begin{abstract}
The program is implemented in the Dasuk County in Sumenep Regency with two goals major producer of cashew Beringin village and Jilbudan village. The program IBW has a purpose: 1) to increase welfare better society through the utilization of local resources that have economic value, 2) increasing the skills and professionalism of people, 3) increase the capacity of cashew farming communities to diversifying the product, 4) the formation of economic business community and institutions that are structured to cashew farmers. The project used two approaches, Training and mentoring approach. Training approach include: 1) entrepreneurial training; 2) skills training for women and youth based on local resources; 3) training appearance and diversifying the cultivation of cashew products professionally and 4) marketing training through the web and on-line. While this method of assistance include: 1) facilitation of technology transfer for the production of cashew cultivation; 2) facilitation of technology transfer diversifying cashew products in a professional manner; 3) mentoring network strengthening marketing activities and 4) institutional strengthening assistance. Expected outcomes of this program for the second year of this is establishing erpreneurship on society, increasing the skills of women and youth with the waste cashew shell, processed products jam and candied cashews, waste cashew to feed the livestock through several processes of ensiling, the manufacture of the product label and cashew packaging technology products, the establishment of farmer networks
\end{abstract}

Keywords: Training, assistance, technology transfer

\begin{abstract}
ABSTRAK
Program ini dilaksanakan di Kabupaten Dasuk di Kabupaten Sumenep dengan dua tujuan utama produsen jambu mete desa Beringin dan desa Jilbudan. Program IBW memiliki tujuan: 1) meningkatkan kesejahteraan masyarakat lebih baik melalui pemanfaatan sumber daya lokal yang memiliki nilai ekonomi, 2) meningkatkan keterampilan dan profesionalisme masyarakat, 3) meningkatkan kemampuan masyarakat petani jambu mete untuk melakukan diversifikasi produk, 4) Pembentukan komunitas bisnis ekonomi dan institusi yang terstruktur untuk petani jambu mete. Proyek ini menggunakan dua pendekatan, pendekatan Pelatihan dan pendampingan. Pendekatan pelatihan meliputi: 1) pelatihan kewirausahaan; 2) pelatihan keterampilan bagi perempuan dan pemuda berdasarkan sumber daya lokal; 3) penampilan pelatihan dan diversifikasi budidaya produk jambu mete secara profesional dan 4) pelatihan pemasaran melalui web dan on-line. Sedangkan metode bantuan ini meliputi: 1) fasilitasi transfer teknologi untuk produksi budidaya jambu mete; 2) fasilitasi transfer teknologi diversifikasi produk jambu mete secara profesional; 3) mentoring jaringan penguatan kegiatan pemasaran dan 4) penguatan kelembagaan bantuan. Hasil yang diharapkan dari program ini untuk tahun kedua adalah membangun kewiraswastaan di masyarakat, meningkatkan keterampilan perempuan dan pemuda dengan limbah jambu mete, selai produk olahan dan manisan
\end{abstract}


kacang mete, limbah mete untuk memberi makan ternak melalui beberapa proses ensikat, yaitu Pembuatan label produk dan produk teknologi kemasan mete, pembentukan jaringan tani

Kata kunci: Pelatihan, bantuan, transfer teknologi

\subsection{Introduction}

Sumenep regency is located at the eastern end of Madura Island has an area of land and sea with scattered islands totaling

126 islands. This area has the potential of natural resources and socioeconomic potential that can be developed and utilized to improve the welfare of the people including in the fisheries sector, plantation, tourism and natural gas.

Utilization of natural resources in Sumenep not optimal, so that the valueadded wealth has not been fully felt by the community. Agriculture Department data East Java province in 2012 claimed Sumenep Regency has an area of cashew production in East Java widest and the largest cashew producer in East Java

Table 1. Size of Cashew Production Area in Regency / City in East Java

\begin{tabular}{|l|c|}
\hline \multicolumn{1}{|c|}{ Productive Regions } & Area \\
\hline District of Sumenep & 12,258 \\
\hline District of Sampang & 10,619 \\
\hline District of Bangkalan & 9,466 \\
\hline District of Ngawi & 3,083 \\
\hline District of Pamekasan & 2,419 \\
\hline District of Pacitan & 2,118 \\
\hline 26 other Districts & 12,940 \\
\hline
\end{tabular}

Source : Plantation Office of East Java Province, 2012

\subsection{Regional issues}

Cashew fruit plantations have not yet provide maximum economic value for society. Farmers sell their products in the form of unprocessed cashew due to various reasons, they need to quickly get the money, the production scale is small / inefficient and

lack of processing tools. This causes the welfare level Cashew farmers in general is still relatively low. In fact, if the cashew fruits (which is a waste) can be processed further as basic material for various types of commodities processed foodstuffs, then this will be an impact on the increase Cashew farmers welfare.

One main reason is the low quality of public resources. Of a population of 29,469 people, more than $90 \%$ had status of primary school drop outs, and only 5,50\% of population had complete primary school.

Tabel 2. Total Population by Education Level

\begin{tabular}{|c|r|c|}
\hline Educational level & \multicolumn{1}{|c|}{ Total } & \multicolumn{1}{c|}{ In } \\
\hline Elementary Drop Outs & 26.487 & $91,10 \%$ \\
\hline Elementary grads & 1.621 & $5,50 \%$ \\
\hline Junior High grads & 538 & $1,83 \%$ \\
\hline High School grads & 351 & $1,19 \%$ \\
\hline Diploma/Bachelor & 112 & $0,38 \%$ \\
\hline Total & 29.469 & $100 \%$ \\
\hline
\end{tabular}

Source : Central Bureau of Statistics, 2013.

The high number of people who have very low educational levels causes:

1. Low quality of human resources.

2. The lack of the ability for communities to improve the quality and diversification of products that have high sales value.

3. Advances in aquaculture technology and marketing techniques Cashew products remain inadequate.

4. Low level of innovation to process waste cashew materials into useful materials and economically valuable.

The limited funds, facilities and infrastructure for the development of the program.

\subsection{Theory on Welfare}

In general, theories of welfare are classified into three, classical utilitarian, neoclassical welfare theory and new contractarian approach (Albert and Hahnel, 2005). 
Classical utilitarian focused that the satisfaction or pleasure of a person can be measured and and even grow. The level of satisfaction for each individual can be compared quantitatively. Neoclassical welfare supports Optimality Pareto principle, "the community Becomes better off if one individual non Becomes better off and worse off'. While new contractarian approach each individual has their concept of maximum freedom in his life.

The third view emphasizes that the level of well-being depends on the level of satisfaction and pleasure that can be achieved in life. High level of welfare can be achieved when a behavior is able to maximize the level of satisfaction in accordance with available resources. Of the three levels of well-being published by Albert and Hahnel, the condition is now more directed at new contractarian approach because everyone can reach the level of prosperity in accordance with its resources.

Welfare is a state in which all citizens, without exception and wherever located, always in a state of self sufficiency all their needs both materially and spiritually, security and public order is guaranteed, peaceful life, less crime and no suspicion, as well as the entire state apparatus together uphold the authority of the state and nation.

Broadly speaking welfare measures can be divided into two indicators of economic indicators and indicators of non-economic (social) (Todaro, 2003: 234).

\section{Economic Indicators}

The income per capita as an indicator of society is often referred as economic indicators or monetary indicators. It also often used as an indicator of the economic level progress among developed countries to the developing countries. It gives an overview of the growth rate of public welfare in various countries, also illustrates the differences in the level of welfare of various countries.

Income per capita as an indicator of society has the advantage of capable of focusing development on rising levels of life and eliminating poverty. Income per capita is the best indicator of well-being that is at the moment

\section{Social Indicators}

Another way to compare the level of welfare in various countries by using data that aren't commonly known is monetary or non- monetary indicators of social indicators.

Indicators of the level of welfare on each state is determined based on the level of consumption or the amount of inventory of goods to certain data is easily obtained, such as:

1. Life expectancy

2. Animal protein consumption

3. Energy and Electricity consumption

4. Steel consumption

Indicators of human well-being drafted by the United Nations Development Program, known as the Human Development Index or the Human Development Index rank all countries, both developed and developing countries on a scale of 0 to 1 (Todaro 2003: 68).

Human welfare is arranged by three components:

1. Life expectancy that obtained from the calculation of the average number of children born alive and the average number of children still alive reffering to mothers group age 15-49 years old;

2. The level of education is measured by two indicators: literacy and average length of educational time. The adult literacy rate is the percentage of population aged 15 years and over who can read and write. This indicator is a of two-thirds part, the other onethird part is an indicator of the average length of school;

3. The decent standard of living, by using the average spending per capita in real terms. 


\subsection{Outcomes}

Overall, the target to achieve in this three years program is an increase of welfare for a better society through the use of local resources that have economic value, increasing the skills and professionalism of the public, increasing the ability of people to do the diversification of products, and the formation of economic business community and institutions that are structured to cashew farmers.

Sumenep Government's efforts to improve community welfare through local economic development has been written in Sumenep Regency Goverments Guidance Year 2011-2015. To achieve this mission, the Government has been doing counseling, discussions with the Information Society Forum (FIM) Sumenep, as well as management training estates are properly adjusted to the contour of the ground. But had trouble, because the low level of education and the mindset of the majority of farmers are still pragmatic, ie how can immediately earn money in the short term and fast, in order to meet their basic needs.

Table 4: Program‘s Target In District Dasuk, Sumenep Year 2015 -2017

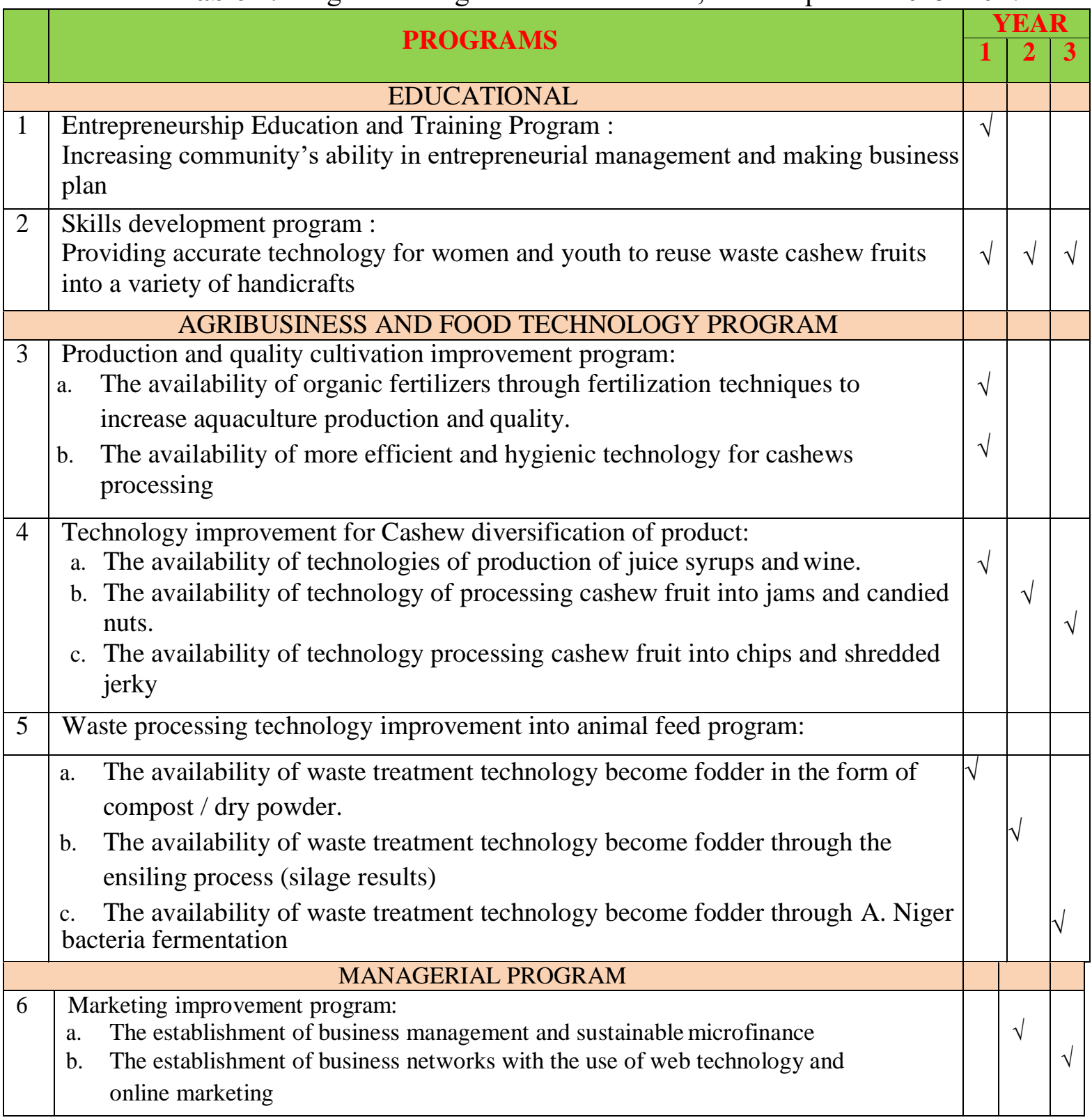




\begin{tabular}{|l|l|c|c|}
\hline 7 & $\begin{array}{l}\text { Product packaging and labeling technology Program: } \\
\text { a. The availability of packaging technology } \\
\text { b. Label-making capabilities and trademark maintenance }\end{array}$ & $\sqrt{ }$ \\
& $\sqrt{ }$ \\
\hline 8 & $\begin{array}{l}\text { Strengthening Institutional Capacity: } \\
\text { a. Establishment of farmers union (Gapoktan) } \\
\text { b. The establishment of a cashew farmers' network groups in the district Dasuk }\end{array}$ & $\sqrt{ }$ & $\sqrt{ }$ \\
\end{tabular}

\subsection{Implementation Methods}

To make people more independent and prosperous, then the handling of the three aspects of society, namely:

1. Aspects of education, through entrepreneurship education and increased knowledge about the cultivation of cashew which provides more economic value

2. Aspects of agribusiness and food technology, through the introduction of appropriate technologies for the management of Cashew and waste generated.

3. The management aspects, especially marketing management, which can be seen from the side of the product packaging to the marketing distribution.

One area in Sumenep that has the potential to grow and become more independent society is the District Dasuk which has an area of $64.50 \mathrm{~km} 2$, with 15 existing village territory. This district is the largest producer of cashew fruit in Sumenep regency. Cashew seed yield of this region is heavily exported out of the island and abroad. Unfortunately, the level kesehjateraan plantation farmers and communities in the region in general is still relatively low.

\section{Two approaches in the methods of implementation:}

1. Training Methods:
- Entrepreneurship training

- Skills training for women and youth based on local resources.

- Training appearance and diversification of aquaculture products in a professional cashew

- Marketing training via the web and on- line

2. Assist Method :

- Facilitation of technology transfer for the production of cashew cultivation

- Diversifying technology the accompaniment rather cashew products in a professional manner mentoring network strengthening marketing activities

- Institutional strengthening assistance In the process, the method of implementation for each program a solution to solve the problem is as follows:

1. Entrepreneurship education and training will be given to member of community in Dasuk district, eithern business owners or not, through of education, simulation and mentoring.

The training subjects include entrepreneurship motivation and business development management. To monitor its implementation, team will provide guidance as well as a consultant.

The program to improve the cultivation of cashew production and quality through technological development fertilizer processing, and processing unprocessed cashew.

2. Processing technology improvement for diversify cashew into a variety of food i.e juice, syrup, spread and floss. 


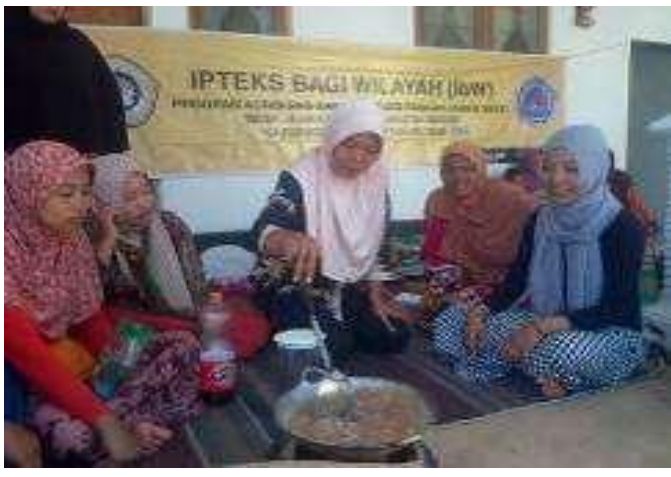

Figure 1: Cashew syrup recipe training

3. Technology improvement for cashew waste reuse into animal feed via dry powder technology, methods of silage and fermentation methods.

4. Business Development Program for products labeling and packaging through training on how to conduct a hygienic packaging and high sale value labeling.

5. Promotion and marketing knowledge training to use the computer for online marketing.

6. Strengthening institutional capacity will be implemented in the second and third year to establish cashew farmers' groups union.

\section{Selection of Higher Education Partners}

Colleges are made partners in this activity are the University Wiraraja reasons:

1. The location of the institution is near the target area. It will be easier to facilitate the coordination of the program.

2. They know more about the local community's character.

3. Staff lecturers are included in this program in accordance with the required specifications.

\section{Contributions of Government of Sumenep Region}

In the implementation, the district government of Sumenep contribute in the form:

1. Provide matching funds to support educational programs and training for the targeted communities and for purchasing of materials and equipment required.

1. Facilitate the communication, particularly the target areas in order to run well and get support from the community and the relevant authorities, both at the village level and the district level.

2. Communicating the implementation of science and technology program for the region to SKPD related, so each SKPD related planning and activities together during the implementation of the program.

Opt number of local government's field staff to learn the science and technology implementation.

\subsection{Results}

1. Education and Training Program of entrepreneurship:

Improving the ability of people in the motivation of entrepreneurship, creation of business plans and business development management, followed by a simulation for the PKK and Karang Taruna. In this event, we provide a variety of gift-making skills, brooches and ornaments for the veil of material cashew nut shell waste and attended by 50 people representing the village.

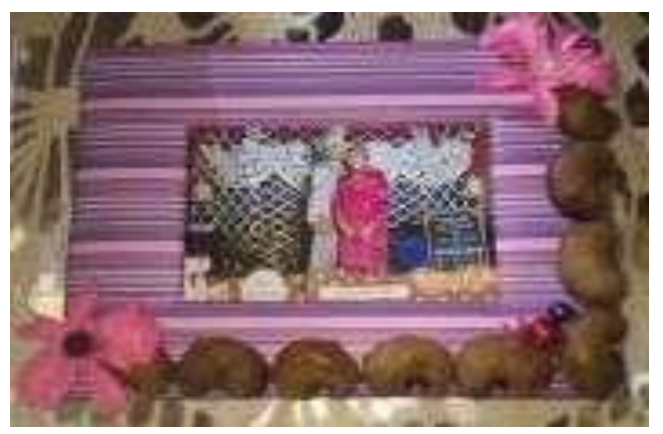

Figure 2:

Picture frame decorated with cashew shells

2. The program to improve the cultivation of cashew nut production and quality: Introduce the process of 
making organic fertilizer from the rind cashew chopped and mashed. We made a count tool and grinder automatic skin that produce a dry powder

3. The program to improve processing technology:

We provide counseling and workshops increase fruit processing technology to diversify into a variety of food cashew juice, syrup, spread, and floss. Through this program we created a tool to squeeze the cashew fruit into juice and separate the waste automatically.

The farmers' housewives and the teenagers are now having an entrepreneurship activity of producing and selling the consumable recycled waste fruit.

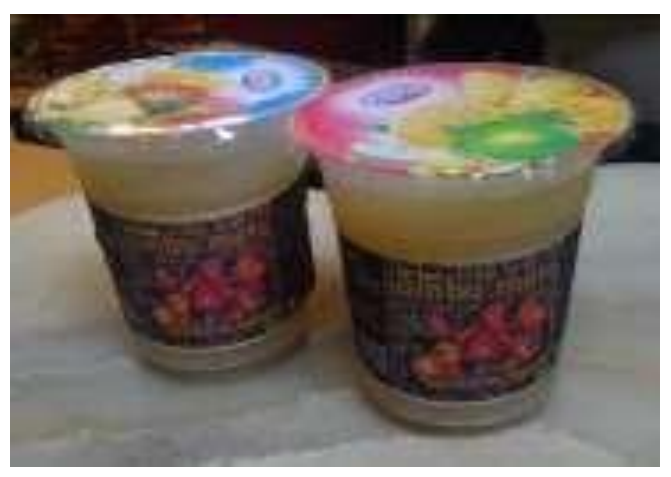

Figure 3: Cashew fruit juice

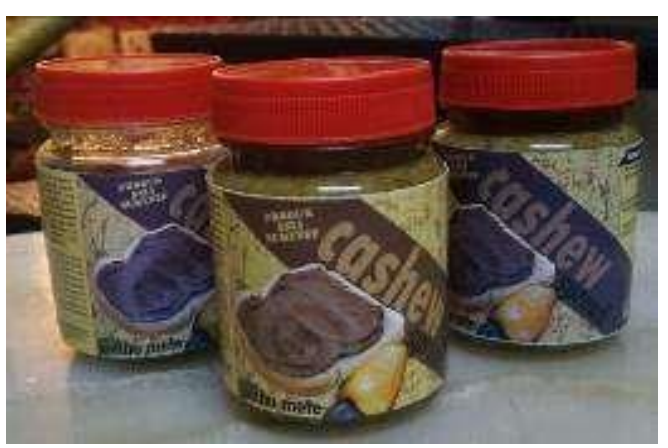

Figure 4: Cashew spread

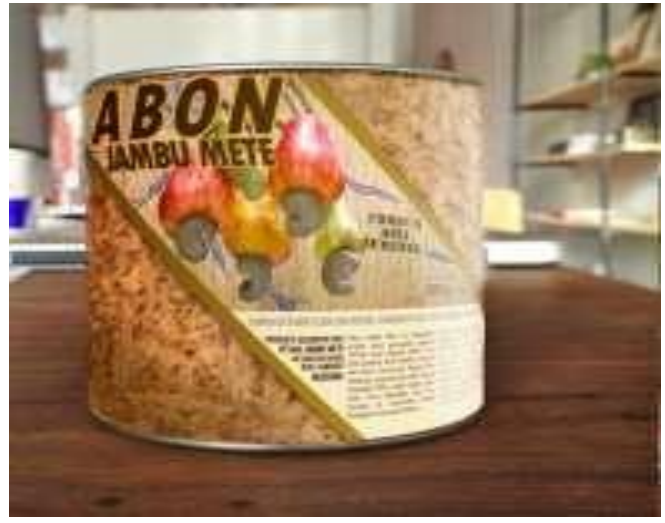

Figure 5: Cashew floss

4. The program to improve technologies for waste cashew:

Introduce knowledge and processing of various wastes such as shells cashew cashews and cashew fruit bodies processed into animal feed through to the third selection method, namely dry powders, methods of silage and fermentation methods.

The composition of animal feed use of waste cashew nuts are $30 \%$ of the total feed. Fodder from cashew fruit waste have resulted in increased protein $12 \%$ to $20.84 \%$.

Fodder dry powder

Cashews milled waste directly mixed with animal feed ingredients.

Silage Methods:

Fermented cashew fruit flesh anerobik solid substrate and allowed to stand for 2 weeks until the protein content reaches $12 \%$.

\section{Fermentation method:}

The powder of dried fruit is fermented at a temperature of $37^{\circ} \mathrm{C}$ for 5 days by adding aspergillus niger bacteria 2228, mycerothecin verrucaria trichoderma iride 2100 and 2569.

5. Business Development Program: Counseling and training on media packaging products plastic or cans correct and hygienic, good cashews and cashew other diversified products.

Continued synergistically with training to make label design attractive products as well as how to 
take care of trademark rights for products sold.

6. The program to improve marketing technologies:

Extension activities on techniques of marketing and promotion as well as training in the use of computer networks for marketing through online media.

7. Strengthening institutional capacity: Establishing farmers union, followed by forming a network. Establishment of this network of farmer union expected to elevate the communication and cooperation among farmers' groups and also to strengthen the marketing of their products out, even up to export.

\subsection{Conclusions}

By sharing our knowledge and its implementation to the cash ew farming community in the Dasuk village in district Sumenep Madura, they can now reuse the cashew waste into products that have aesthetic value and sale value. Proceeds from sales of these products becomes additional revenue for the community, which is expected to lift the level of economic and towards community independence.

\section{References}

[1] Badan Pusat Statistik, 2013, Kecamatan Dasuk Dalam Angka 2013, Biro Pusat Statistik Kabupaten Sumenep Jawa Timur, Sumenep.

[2] DP2M Dirjen Dikti, 2013, Panduan Pelaksanaan Penelitian dan Pengabdian Kepada Masyarakat Edisi IX, Kementrian Pendidikan dan Kebuadayaan, Jakarta

[3] Pemerintah Kabupaten Sumenep, 2011, Rencana Pembangunan Jangka Menengah Daerah Kabupaten Sumenep Tahun 2011-2015 -

RPJMD, Sumenep

[4] Saragih, Yan Pieter; Haryadi, Yadi, 1994, METE, Budidaya Jambu Mete. Pengupasan Gelondong. Bogor,
Penebar Swadaya.

[5] Tribunejatim.com, 2011, Pemprop Jatim akan Bagikan 140.000 biji Jambu Mete, Surabaya

[6]

http://matanomo.blogspot.com/2011/12/ab on-dari- jambu-mete.html

[7] http://bisnisukm.com/membukapeluang-usaha- sirup-jambu-mete.html 